\title{
A noteworthy Diderma species from Tanzania
}

\author{
TARJA UKKOLA and MARJA HÄRKÖNEN
}

\begin{abstract}
UKKOLA, T. \& HÄRKÖNEN, M. 2001: A noteworthy Diderma species from Tanzania. - Karstenia 41: 25-29. Helsinki. ISSN 0453-3402.

An unidentified species of Diderma, new to Tanzania, is discussed and illustrated. A scanty specimen developed in a moist chamber culture prepared from bark of living Juniperus procera. This moist chamber was cultured for the first time in June 1989 and produced then no Diderma species after one month of incubation. The dried petri dish was stored for ten years in a closed, dark laboratory cupboard and was rewetted in May 1999. After 60 days of incubation an interesting Diderma species developed with walnut-shaped spores bearing an equatorial ring or two perpendicular rings. This specimen may represent a new species, but also seems to have affinity to Diderma punense. We have not been able to obtain the type specimen of the latter species from India to compare it to our specimen. For comparison, some specimens of Diderma cor-rubrum with similar spore morphology were studied with SEM.
\end{abstract}

Tarja Ukkola and Marja Härkönen, Department of Ecology and Systematics, P.O. Box 7, FIN-00014 University of Helsinki, Finland

\section{Introduction}

In May-June1989, during the rainy season, the second author and Ms. Tiina Saarimäki collected mushrooms and myxomycetes in Tanzania. In addition to field collections material was collected for moist chamber cultures. The Department of Ecology and Systematics, University of Helsinki made a total of eight field trips in 1988-1995 to different parts of Tanzania. Results of the myxomycete collections made during these trips were published in Härkönen and Saarimäki (1991, 1992, 1994), Ukkola and Härkönen (1996), Ukkola et al. (1996), Ukkola (1998a, b,c), Ukkola (2000), and Härkönen and Ukkola (2000).

In May 1999 the authors rewetted some of the moist chamber cultures that were incubated for the first time in 1989. In one of the cultures an interesting Diderma species developed. We have not been able to identify it so far, but since the species has very interesting spores, we describe, illustrate and discuss this taxon and other closely related Diderma species. For comparison, specimens of Diderma cor-rubrum $\mathrm{T}$. Macbr. were studied with SEM.
For more details of the results of the rewettings of the ten year old cultures see Härkönen and Ukkola (2000).

\section{Material and methods}

Moist chamber cultures were prepared with bark samples collected from living Tanzanian trees in May-June 1989 and wetted in Finland on 6 June 1989. The petri dishes were kept in an incubator at $25^{\circ} \mathrm{C}$, and lit artificially in a $12: 12 \mathrm{~h}$ cycle. During the incubation, mature sporangia were removed. After one month the dishes were dried and stored for ten years in a closed, dark laboratory cupboard. In May 1999 the chambers were rewetted and incubated in normal room conditions in diffuse daylight for two months. To prevent any new contaminations, the wetting and any other opening of the cultures, was made in a sterile room radiated beforehand with UV light. In one of the rewetted cultures after 60 days of incubation a Diderma species developed. The specimen is scanty, consisting of only fifteen mature sporangia. A third rewetting of the culture no further produced material, and the spores did not germinate in a hanging drop of water (see Farr 1981), nor on oat agar. The specimen is deposited at the Botanical Museum of the University of Helsinki $(\mathrm{H})$. It is too scanty to serve as a type specimen of a new species (and its affinity to Diderma punense Patil, Mishra \& Ranade (as 'punen- 
sis $\left.^{\prime}\right)$ is still unclear) but, as it is very unique and well matured, we describe it here.

For SEM studies some dried sporangia were dehydrated with $0.1 \mathrm{M}$ phosphate buffer $(\mathrm{pH} 7.3$ ), and fixed in $2.5 \%$ glutaraldehyde at $+4^{\circ} \mathrm{C}$ overnight. After proper rinsing in buffer the sporangia were put in an ethanol series $(50 \% 2 \times 5 \mathrm{~min} ., 70 \%$ for $24 \mathrm{~h}, 94 \% 2 \times 10 \mathrm{~min}$., $100 \%$ for $24 \mathrm{~h}$ ), after which they were dried with critical point using Balzers CPD 020 Critical Point dryer. Spor-
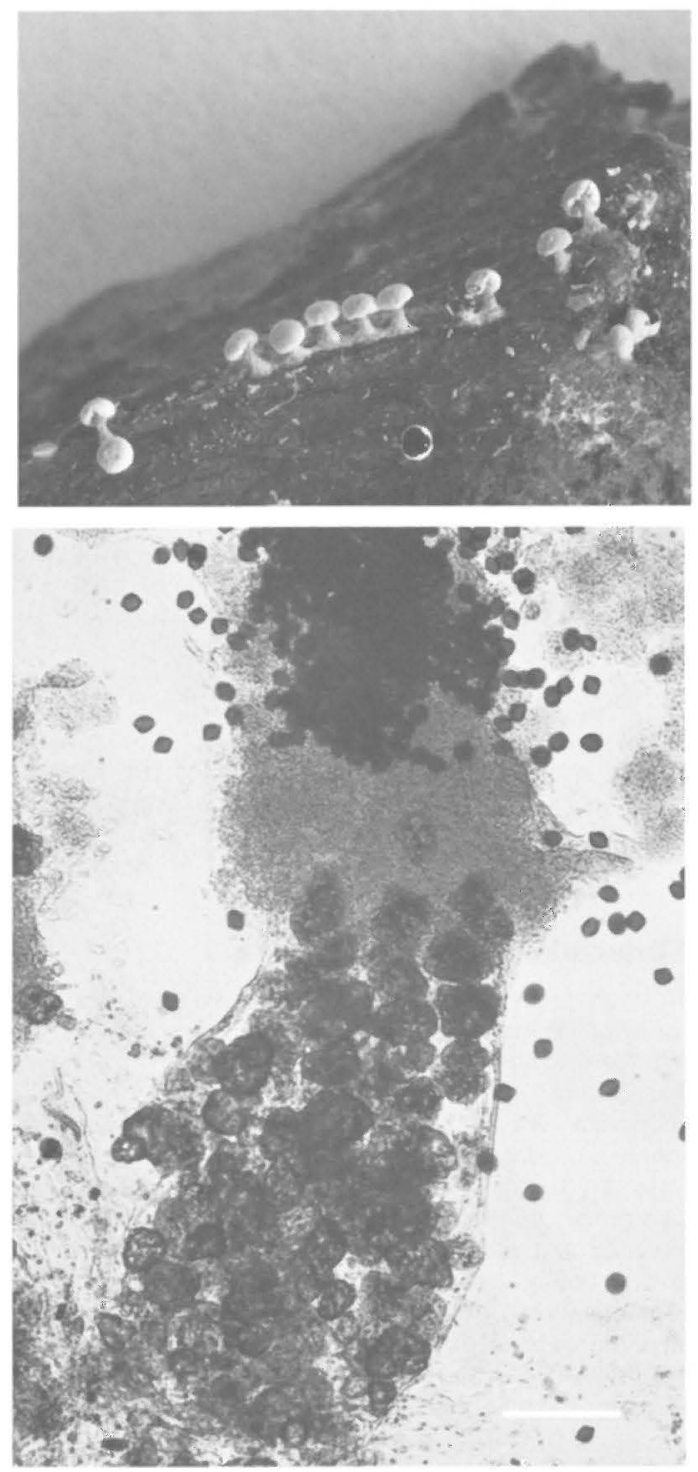

Figs. 1-2. Diderma sp. from Tanzania (Marja Härkönen 4123). - 1. Sporangia. 2. Light microscopy photograph showing the stalk filled with large calcareous granules (darker in this photo than seen by transmitted light), the columella, and the walnut-shaped, dark spores. Bar= $100 \mu \mathrm{m}$. angia were mounted with graphite glue on aluminium stubs and coated with platinum in a Jeol Fine Coat JFC1100 sputter $(25 \mathrm{sec}$.), and observed with a Jeol JSEM820 scanning electron microscope using $10 \mathrm{kV}$ in the Institute of Biotechnology, Electron Microscopy Unit, University of Helsinki.

\section{The Tanzanian Diderma species Figs. 1-8}

Specimen examined: Tanzania. Northern Province, Arusha District. Caldera of Mt. Meru, alt. ca. 2600 m, developed in moist chamber culture prepared with bark of living Juniperus procera, May 1989 Härkönen 4123 (H). First incubation on 6.VI.-8.VII.1989, culture rewetted on 12.III.1999, sporangia developed on 10.V.1999.

Sporangia in a small group, stalked, hemispherical, depressed and wrinkled below, white to cream-coloured; total height $0.8-1.2 \mathrm{~mm}$, ca. $0.5-$ $0.7 \mathrm{~mm}$ in diameter. Stalk thick, about half or little more of the total hight, pale staw-yellow, knobbly from protruding calcareous nodes, filled with large, tetragonal and rounded lime crystals. Hypothallus inconspicuous, common to the group. Peridium double, outer layer whitish, egg shelllike, composed of closely aggregated, globose calcareous granules, inner layer thin, whitish on the upper parts, pale yellowish brown and divided with pale bands on the lower parts. Columella small, depressed, pulvinate, round when seen above, concolorous with the stalk. Capillitial threads sparse, thin, pale brown to nearly hyaline, occasionally with a few brown nodules. Spores black in mass, purple-brown by transmitted light, walnut-shaped with an equatorial, saturnoid ring, or often with two rings arranged perpendicularly to each other, very minutely warted or roughened, nearly smooth by light microscope, with SEM the outer layer of the spore wall roughened, "fluffy" often scaling away and exposing the inner, rougnened wall; spores $12-$ $14.3-17 \mu \mathrm{m}$ in diameter.

\section{Discussion}

The peeling of the outer spore wall was visible only in SEM (Figs. 5-8), by light microscope with oil-immersion there was no sign of it. In spite of fixing with glutaraldehyde, it is probable that the peeling is an artefact caused by prepatory treatments for SEM.

The Tanzanian Diderma species seems to be closest to Diderma punense, other related species are Diderma cor-rubrum, Diderma marieae 

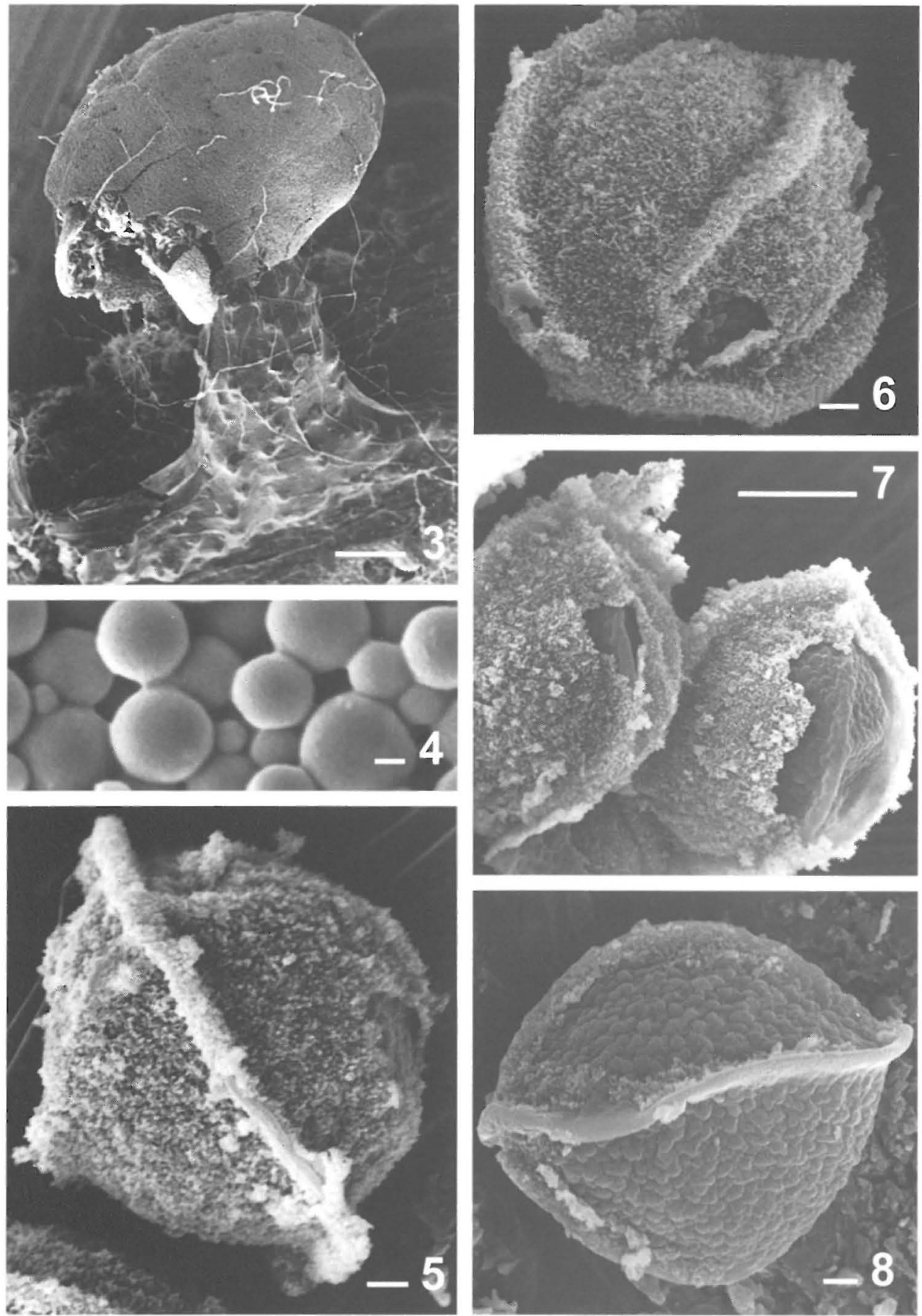

Figs. 3-8. SEM micrographs of Diderma sp. from Tanzania. - 3. Sporangium. Note the knobs on the surface of the stalk caused by large, protruding lime granules. Bar $=100 \mu \mathrm{m} .4$. Globose calcareous granules forming the upper eggshell-like layer of the peridium. Bar $=1 \mu \mathrm{m}$. 5. One spore with roughened, fluffy outer surface, and an equatorial, saturn-like ring. Note the less distinct other ring at right angles to the first. $\mathrm{Bar}=1 \mu \mathrm{m}$. 6 . One spore with two clear rings. Bar $=1 \mu \mathrm{m}$. 7. Two spores in which the outer spore wall is broken. Bar $=5 \mu \mathrm{m}$. 8. One "peeled" spore with roughened wall. Bar. $=1 \mu \mathrm{m}$. 
Patil, Mishra \& Ranade (as 'marie'), and Diderma reticulosporum Nann.-Bremek., K. Mukerji \& R. Pasricha.

Diderma punense has a white, calcareous stalk, thick peridium which dehisces along hexagonal markings; small, nearly dome-shaped to globose, pinkish white columella, dark brown capillitial threads, and walnut like, smooth spores with encircling ring, (12.5-)13-15 $\mu \mathrm{m}$ in diameter (Mishra \& Ranade 1979). We have not been able to obtain the type specimen of $D$. punense that originates from Empress Garden Pune, New Delhi, India (collected on 20 June 1975). The outer peridial layer of the Tanzanian Diderma is smooth (Fig. 3) with no hexagonal plates. The lower inner side, however, has beige areolae, divided by pale bands.

Diderma cor-rubrum has a clavate, greyish purple to deep purplish red columella (Fig. 9), spores are globose to ovate, occasionally apiculate at one or both ends, verrucose (Martin \& Alexopoulos 1969). According to Keller (1970) the apiculation represents a manifestation in optical section of a continuous ring that encircles the surface of the spore. With SEM it really is possible to see a ring around the spores (Figs. 10-11).

Diderma marieae has spherical to subspherical, thick-walled spores, $12.8-16 \mu \mathrm{m}$ in diameter, ornamented with short and stout spines fused to
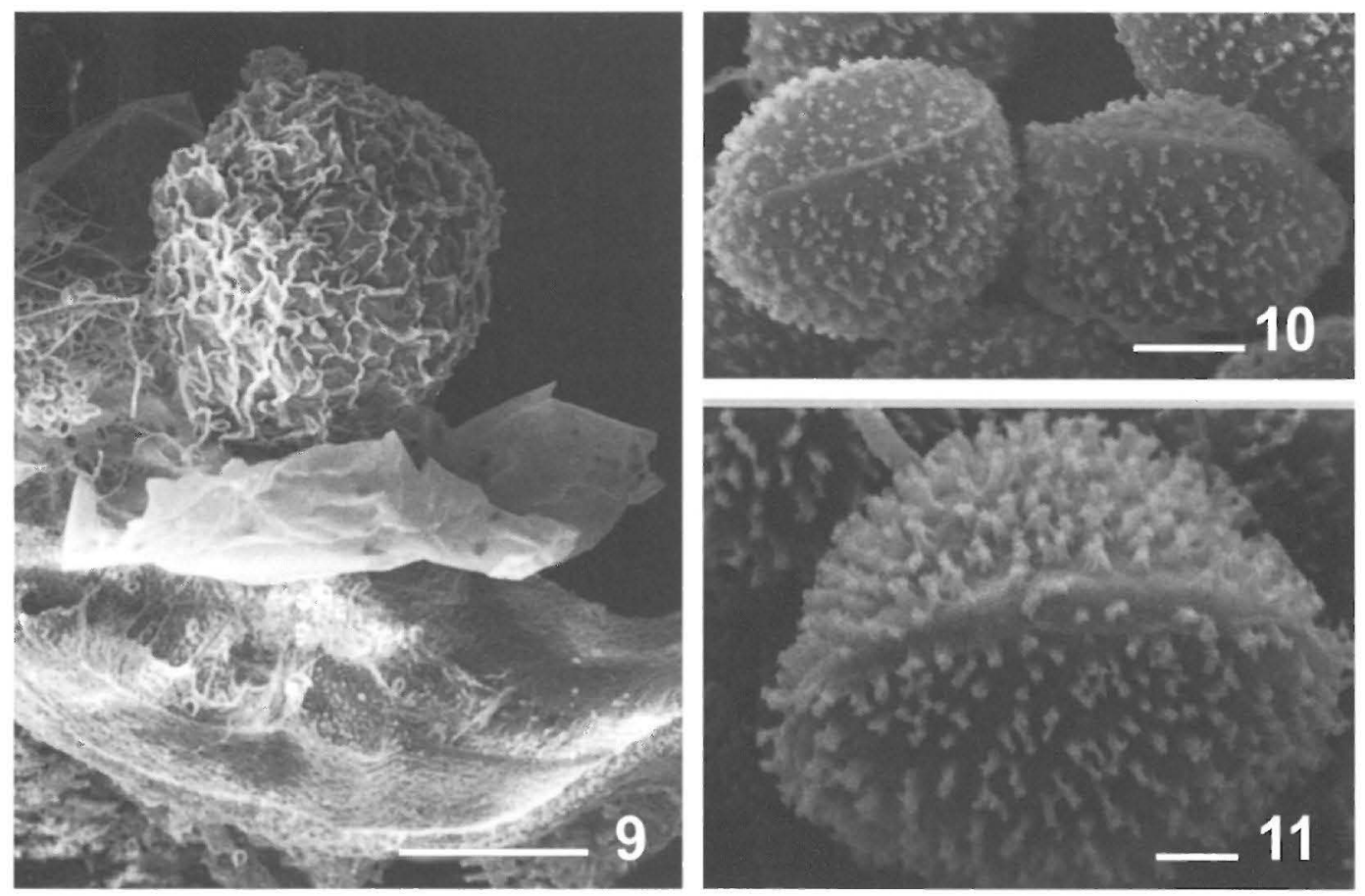

Figs. 9-11. SEM micrographs of Diderma cor-rubrum. - 9. Dehiscent sporangium showing the clavate columella and the membranous inner peridium (USA, T.E. Brooks 1972). Bar $=100 \mu \mathrm{m}$. 10. Two warted spores with equatorial rings (USA, T.E. Brooks 1972). Bar $=1 \mu \mathrm{m}$. 11. Spore ornamented with bacula and a conspicuous ring (India, Thind 7145). $\mathrm{Bar}=1 \mu \mathrm{m}$. 
form an incomplete reticulation and encircled by ridge or ridges (Mishra \& Ranade 1979).

Diderma reticulosporum has subovoid to somewhat lemon-shaped spores with an equatorial, somewhat protruding line, ornamented with a rather small-meshed irregular reticulation, 10 $10.5 \times 13-14 \mu \mathrm{m}$ in diameter (Nannenga-Bremekamp et al. 1984).

Other material studied: Diderma cor-rubrum. USA. Kansas. Riley Co., 1 Oct. 1950 T.E. Brooks 1972 (BPI 813609). India. Sara, Chamba, H.P., 21 Aug. 1966 K.S. Thind 7145 (BPI 813616). Glen, Simla, H.P., on leaves and other dead vegetable matter, 22 Sep. 1967 H.S. Khara 1308 (BPI 813614).

Acknowledgements: We wish to thank the curator of BPI (U. S. National Fungus Collection, Beltsville, USA) for the loans of specimens, and Prof. Harold W. Keller and Mr. David W. Mitchell for reviewing the manuscript.

\section{References}

Farr, M.L. 1981: How to know the true slime molds. Wm. C. Brown Company Publishers, Dubuque, Iowa. $132 \mathrm{pp}$.

Härkönen, M. \& Saarimäki, T. 1991: Tanzanian Myxomycetes: first survey. - Karstenia 31: 1-54.

Härkönen, M. \& Saarimäki, T. 1992: Tanzanian Myxomycetes: first survey (addition). - Karstenia 32: .

Härkönen, M. \& Saarimäki, T. 1994: Myxomycetes, an unexplored class of fungi in Tanzania. - In: Seyani,
J.H. \& Chikuni, A.C. (eds.), Proc. XIIIth Plenary Meeting AETFAT 1:735-748. Zomba, Malawi. 793 pp.

Härkönen, M. \& Ukkola, T. 2000: Conclusions on myxomycetes compiled over twenty-five years from 4793 moist chamber cultures. - Stapfia 73: 105-112.

Keller, H.W. 1970: Didymium saturnus, a new myxomycete occurring on straw stacks. - Mycologia 62: 1061-1066.

Martin, G.W. \& Alexopoulos, C.J. 1969: The Myxomycetes. - Univ. Iowa Press, Iowa City. 560 pp.

Mishra, R.L. \& Ranade, V.D. 1979: Myxomycetes of Maharashtra - II The genus Diderma Pers. - M.V.M. Patrika 14: 33-41.

Nannenga-Bremekamp, N.E., Mukerji, K.G. \& Pasricha, R. 1984: Notes on India Myxomycetes. Three new species, and comments on others. - Proc. Kon. Nederlandse Akad. Wetensch. C. 87: 471-482.

Ukkola, T. 1998a: Some myxomycetes from Dar es Salaam (Tanzania) developed in moist chamber cultures. - Karstenia 38: 27-36.

Ukkola, T. 1998b: Myxomycetes of the Usambara Mountains, NE Tanzania. - Acta Bot. Fennica 160: $1-37$.

Ukkola, T. 1998c: Tanzanian Myxomycetes to the end of 1995. - Publ. Bot. Univ. Helsinki 27: 1-45. PhD. thesis.

Ukkola, T. 2000: A check list of Tanzanian Myxomycetes. - Karstenia 40: 189-194.

Ukkola, T. \& Härkönen, M. 1996: Revision of Physarum pezizoideum var, pezizoideum and var. microsporum (Myxomycetes). - Karstenia 36: 41-46.

Ukkola, T., Härkönen, M. \& Saarimäki, T. 1996: Tanzanian Myxomycetes: second survey. - Karstenia 36: 51-77. 